\title{
Effect of Buflomedil (4-(1-Pyrrolidinyl)-1-(2,4,6-Trimethoxy Phenyl)- 1-Butanone Hydrochloride) on the Function of Striatal Dopaminergic Neurons
}

\author{
Hirohumi KODA, Tsuneichi HASHIMOTO and Kinya KURIYAMA \\ Department of Pharmacology. Kyoto Prefectural University of Medicine. \\ Kamikyo-ku, Kyoto 602, Japan \\ Accepted October 20. 1988
}

\begin{abstract}
Effect of buflomedil (4-(1-pyrrolidinyl)-1-(2,4,6-trimethoxy phenyl)-1butanone hydrochloride) on the release and uptake of dopamine (DA) and the function of DA receptors in the striatum was investigated using male Wistar rats. In vitro addition of buflomedil $\left(10^{-5}-10^{-8} \mathrm{M}\right)$ had no effect on the uptake of $\left[{ }^{3} \mathrm{H}\right]$ DA in striatal slices. On the other hand, buflomedil $\left(10^{-5}-10^{-7} \mathrm{M}\right)$ increased the spontaneous as well as high $\mathrm{K}^{+}(30 \mathrm{mM})$-evoked releases of $\left[{ }^{3} \mathrm{H}\right.$ ] DA from striatal slices. Buflomedil inhibited the bindings of $\left[{ }^{3} \mathrm{H}\right] \mathrm{SCH} 23390,\left[{ }^{3} \mathrm{H}\right]$ spiperone and $\left[{ }^{3} \mathrm{H}\right]$ apomorphine to striatal D1, D2 and D3 receptors only at a high concentration. On the other hand, buflomedil inhibited $\left[{ }^{3} \mathrm{H}\right.$ ] quinuclidinyl benzilate (ONB) binding to striatal muscarinic cholinergic receptors, which was similar to the action of carbachol. Pretreatment with scopolamine $(0.5 \mathrm{mg} / \mathrm{kg})$ in vivo inhibited the facilitation of striatal DA turnover induced by oral administration of buflomedil ( 300 $\mathrm{mg} / \mathrm{kg}$ ). In contrast, continuous oral administration of buflomedil ( $30 \mathrm{mg} / \mathrm{kg} \times 7$ days) to rats had no significant effect on the specific bindings of $\left[{ }^{3} \mathrm{H}\right] \mathrm{SCH} 23390$, $\left[{ }^{3} \mathrm{H}\right]$ spiperone, $\left[{ }^{3} \mathrm{H}\right]$ apomorphine and $\left[{ }^{3} \mathrm{H}\right] \mathrm{ONB}$ to synaptic membrane preparations obtained from the striatum. These results suggest that buflomedil may enhance striatal DA release by stimulating muscarinic cholinergic receptor and that DA receptors may not be involved in the enhancing effect of buflomedil on DA release.
\end{abstract}

Buflomedil (4-(1-pyrrolidinyl) - 1-(2,4,6trimethoxy phenyl)-1-butanone hydrochloride) is a vasoactive agent which improves the circulation in peripheral and central blood vessels. For example, it has been shown that intravenous administration of buflomedil to anesthetized dogs induces the increase of femoral and cutaneous blood flows (1). In isolated dog arteries, it has been also shown that buflomedil reversibly blocks $\alpha$-adrenoceptors and possesses an anti-nicotine action (2). Similarly, buflomedil was found to increase the blood flow of forefoot skin in patients suffering from peripheral arterial diseases as well as that in calf muscle (3). Courbier et al. (4) also reported that buflomedil improved the vasomotor reactions to cold stimulus in Raynaud's patients. In addition, it has been found that buflomedil improves various neuropsychiatric symptoms associated with chronic cerebrovascular diseases in elderly patients $(5,6)$. In addition, we previously reported that oral administration of buflomedil induced the facilitation of metabolic turnover of dopamine (DA) in rat striatum (7). In the present study, we have investigated the effect of buflomedil on the release and uptake of DA as well as on the function of DA i eceptors in the striatum using male Wistar rats in order to clarify the mechanism underlying the buflomedil-induced enhancement of striatal DA turnover.

\section{Materials and Methods}

Animals used: Male Wistar rats (180$230 \mathrm{~g}$ ) were used for this study. These animals given free access to laboratory chow (MF; Oriental Yeast, Co., Ltd.) and tap water. 
All experiments were initiated at 10:00 a.m. in order to avoid circadian variations in the functional states of central dopamine neurons.

Drug administration: Buflomedil hydrochloride (Dainabot Co., Ltd.) was dissolved in distilled water, and the final volume given to each animal was adjusted to $1 \mathrm{ml} / 100 \mathrm{~g}$ body weight. For single oral administration, $300 \mathrm{mg} / \mathrm{kg}$ of buflomedil was used, while $30 \mathrm{mg} / \mathrm{kg} /$ day of buflomedil was given orally for 7 days to examine the effect of continuous administration of this drug. The same volume of vehicle was given orally to each control group. Scopolamine $(0.5 \mathrm{mg} / \mathrm{kg})$ was administered subcutaneously at $30 \mathrm{~min}$ before the single oral administration of buflomedil. One hour after the last administration of buflomedil, rats were killed by focussed microwave irradiation $(5 \mathrm{~kW}$, for 0.7 $\mathrm{sec}$ ) to determine dopamine and its metabolites in the striatum. On the other hand. animals were killed by decapitation when the striatum was employed for measurements of the uptake and release of DA as well as for receptor assays.

Measurement of uptake and release of $\left[{ }^{3} \mathrm{H}\right]$ DA: Animals were decapitated, and the brain was rapidly removed and placed on an ice-cold plastic plate. The striatum, dissected according to the method of Glowinski and Iversen (8), was sectioned at $200 \mu \mathrm{m}$ thickness using a microslicer (DTK-1000. Dosaka EM Co., Ltd., Kyoto, Japan). Each striatal slice (3-4 mg) was weighed and then placed in a small plastic vessel equipped with a nylon mesh at the bottom (9). The slice was then preincubated for $15 \mathrm{~min}$ at $37^{\circ} \mathrm{C}$ in $5 \mathrm{ml}$ of incubation medium. The medium was oxygenated Krebs-Ringer bicarbonate buffer ( $\mathrm{pH}$ 7.4) containing $105 \mathrm{mM} \mathrm{NaCl}, 4.2 \mathrm{mM}$ $\mathrm{KCl}, 2.2 \mathrm{mM} \mathrm{CaCl} \cdot 2 \mathrm{H}_{2} \mathrm{O}, 1.0 \mathrm{mM} \mathrm{KH}_{2} \mathrm{PO}_{4}$, $1.0 \mathrm{mM} \mathrm{MgSO}_{4} \cdot 7 \mathrm{H}_{2} \mathrm{O} .25 \mathrm{mM} \mathrm{NaHCO}_{3}, 10$ $\mathrm{mM}$ D-glucose, $0.1 \mathrm{mM}$ ascorbic acid and $20 \mu \mathrm{M}$ pargyline. The slice was then incubated for $15 \mathrm{~min}$ in $1 \mathrm{ml}$ of the medium containing $0.1 \mu \mathrm{M}\left[7.8{ }^{3} \mathrm{H}\right] \mathrm{DA}$ and $10^{-5}$ $10^{-8} \mathrm{M}$ buflomedil. The reaction was terminated by the addition of $3 \mathrm{ml}$ of the ice-cold medium, and the slice was then rinsed twice with $1.5 \mathrm{ml}$ of the ice-cold medium. The radioactivity in the tissue, which was solubilized with $0.2 \mathrm{ml}$ of $1 \mathrm{M}$ Hyamine $10 \mathrm{X}-\mathrm{OH}$. was measured using Triton-toluene scintillant [0.5\% 2.5-diphenyloxazole (PPO), 0.03\% 1,4di 2-(5-phenylosazolyl)] benzene (POPOP). and $33 \%$ Triton $X-100$ in toluene] and $a$ Packard 3379 liquid scintillation spectrometer. In the case of the measurement of $\left[{ }^{3} \mathrm{H}\right] \mathrm{DA}$ release, the slice was incubated for $30 \mathrm{~min}$ in $1 \mathrm{ml}$ of the medium containing 0.1 $\mu \mathrm{M}\left[{ }^{3} \mathrm{H}\right] \mathrm{DA}$. The preloaded slice was rinsed twice with $1.5 \mathrm{ml}$ of the medium, and the vessel containing the slice was transferred successively to a vial containing $1.0 \mathrm{ml}$ of the medium at a $2 \mathrm{~min}$ interval. During the slow phase of $\left[{ }^{3} \mathrm{H}\right]$ DA release (following 16 min of successive incubations at 2-min intervals), the slice was stimulated for $2 \mathrm{~min}$ by the addition of $30 \mathrm{mM} \mathrm{KCl}$. The radioactivity in each vial and the tissue was measured using the same liquid scintillation spectrometer as discribed above. The net uptake of $\left[{ }^{3} \mathrm{H}\right] \mathrm{DA}$ was estimated by subtracting the blank value in the presence of $1.0 \mathrm{mM}$ DA from each datum obtained, and data for the release of $\left[{ }^{3} \mathrm{H}\right]$ DA were expressed as percentage release $[100 \times$ radioactivity released during $2 \mathrm{~min} /$ (total radioactivity released+radioactivity remaining in the tissue)] and subjected to a compartmental analysis by the "peeling off" technique to calculate the rate constant (RC) and half time $\left(t_{1 / 2}\right)(10,11)$.

Receptor assay: To prepare the striatal particulate fraction, the striatal tissue was dissected on ice and homogenized by a Polytron (setting 6 , for $30 \mathrm{sec}$ ) in $20 \mathrm{ml}$ of ice-cold $50 \mathrm{mM}$ Tris- $\mathrm{HCl}$ buffer $(\mathrm{pH}$. 7.4). The homogenate was centrifuged at $48,000 \mathrm{~g}$ for $20 \mathrm{~min}$, and the pellet obtained was washed twice by repeated homogenization and centrifugation. The final pellet thus obtained was suspended in the buffer used in each receptor assay. Striatal synaptic membrane was prepared according to the method of Arana et al. (12). The specific binding of $\left[{ }^{3} \mathrm{H}\right] \mathrm{SCH} 23390$ to $\mathrm{DA} \mathrm{D}_{1}$ type receptor was determined by incubating the striatal particulate fraction (70-120 $\mu \mathrm{g}$ of protein) with $1.0 \mathrm{nM}$ of $\left[{ }^{3} \mathrm{H}\right] \mathrm{SCH} 23390$ for $30 \mathrm{~min}$ at $37^{\circ} \mathrm{C}(13)$. Specific binding was defined as total binding minus nonspecific binding obtained in the presence of $10 \mu \mathrm{M}$ (+)butaclamol. 
DA $D_{2}$ type receptor was assayed using the particulate fraction of the striatum (100-150 $\mu \mathrm{g}$ of protein), which was incubated with $0.5 \mathrm{nM}$ of $\left[{ }^{3} \mathrm{H}\right]$ spiperone in the presence of ketanserin for $60 \mathrm{~min}$ at $37^{\circ} \mathrm{C}(14)$. Specific binding was defined as the total binding minus nonspecific binding obtained in the presence of $10 \mu \mathrm{M}(+)$ butaclamol.

$D A D_{3}$ type receptor was assayed in striatal synaptic membrane preparation (70-100 $\mathrm{kg}$ of protein) incubated with $1.0 \mathrm{nM}$ of $\left[{ }^{3} \mathrm{H}\right]$ apomorphine for $30 \mathrm{~min}$ at $25^{\circ} \mathrm{C}$ as described by Arana et al. (12). Specific binding was defined as total binding minus nonspecific binding in the presence of $10 \mu \mathrm{M}$ dopamine. Muscarinic cholinergic receptor was assayed using $0.3 \mathrm{nM}\left[{ }^{3} \mathrm{H}\right]$ quinuclidinyl benzilate (QNB) (15). Striatal particulate fractions were incubated with $\left[{ }^{3} \mathrm{H}\right]$ QNB for $60 \mathrm{~min}$ at $25^{\circ} \mathrm{C}$. Specific binding was defined as total binding minus nonspecific binding obtained in the presence of $1 \mu \mathrm{M}$ atropine.

The reactions for each receptor assay were terminated by rapid filtration on Whatman GF/B filters. The filters were rinsed three times with $5 \mathrm{ml}$ of ice-cold buffer used for each assay. The filters were then placed in $10 \mathrm{ml}$ Triton-toluene scintillant and counted for its radioactivity by the same scintillation spectrometer after the filters were allowed to stand for $24 \mathrm{hr}$ at room temperature. The protein content in each sample was determined by the method of Lowry et al. (16).

Measurement of striatal DA and its metabolites: Striatal tissue was homogenized by the aid of a Polytron in 10 vol. of ice-cold 50 $\mathrm{mM}$ perchloric acid which contained a calibrated amount of 3,4-dihydroxybenzylamine (DHBA) as an internal standard, and it was then centrifuged at $48.000 \mathrm{~g}$ for $20 \mathrm{~min}$ at $4{ }^{\circ} \mathrm{C}$. The resulting supernatant was stored at $-80^{\circ} \mathrm{C}$ and subjected to the determination of DA and its metabolites. The contents of DA and its metabolites were determined using a Yanaco L-4000W HPLC with a VMD-101A electrochemical detector and a Yanapack ODS-A reverse-phase column (particle size of $10 \mu \mathrm{m}: 25 \times 0.4 \mathrm{~cm}$ internal diameter) (Yanaco Ltd., Kyoto, Japan), according to the method of Wagner et al. (17) with some modifications. The mobile phase was $0.1 \mathrm{M}$ potassium dihydrogen phosphate/ phosphoric acid buffer (pH. 3.2) containing $10 \mu \mathrm{M}$ EDTA, $2.5 \mathrm{mM} 1$-octanesulfonic acid sodium and methanol (18\%). The flow rate of the mobile phase and detector potential were set at $1 \mathrm{ml} / \mathrm{min}$ and $0.8 \mathrm{~V}$ against an $\mathrm{Ag} / \mathrm{AgCl}$ electrode, respectively.

Statistical analysis: Results were expressed as the mean \pm S.E.M., and statistical significance was determined using Student's $t$ test.

Drug used: Buflomedil hydrochloride was obtained from Dainabot Co., Ltd. (Osaka, Japan). Pargyline hydrochloride, scopolamine hydrobromide and carbachol were purchased from Sigma Chemical Co. (St. Louis., MO. U.S.A). Hyamine 10X-OH. PPO and POPOP were obtained from Nakarai Chemicals (Kyoto, Japan). (+)Butaclamol hydrochloride was purchased from Research Biochemicals, Inc. (Wayland, MA, U.S.A.). Ketanserin tartrate, 1-octanesulfonic acid sodium salt and $( \pm$ ) sulpiride were obtained from Kyowa Hakko (Tokyo, Japan), Aldrich Chemical Co. (Milwaukee, WI, U.S.A) and Fujisawa Pharmaceutical Co. (Osaka, Japan), respectively. $\mathrm{SCH} 23390$ was obtained from Schering Japan (Tokyo, Japan). [7,8-3H]dopamine $(29.9 \mathrm{Ci} / \mathrm{mmol}),\left[\mathrm{N}\right.$-methyl- $\left.{ }^{3} \mathrm{H}\right] \mathrm{SCH} 23390$ (85 Ci/mmol) and $\left[{ }^{3} \mathrm{H}\right]$ spiperone $(83.7 \mathrm{Ci} /$ $\mathrm{mmol}$ ) were obtained from Amersham Japan (Tokyo, Japan). L-(-)-[8,9-3H]apomorphine $(28.3 \mathrm{Ci} / \mathrm{mmol})$ and $\left[{ }^{3} \mathrm{H}\right] \mathrm{ONB}(43.6 \mathrm{Ci} /$ mmol) were obtained from New England Nuclear (Boston, MA, U.S.A).

\section{Results}

Effect of buflomedil on uptake and release of dopamine: To clarify the neurochemical mechanism underlying buflomedil-induced enhancement of striatal DA turnover, effects of buflomedil on the uptake and release of $\left[{ }^{3} \mathrm{H}\right]$ DA in striatal slices was investigated. In vitro addition of buflomedil $\left(10^{-8}-10^{-5} \mathrm{M}\right)$. however, had no significant effect on the uptake of $\left[{ }^{3} \mathrm{H}\right] \mathrm{DA}$ into striatal slices. The spontaneous release of preloaded $\left[{ }^{3} \mathrm{H}\right] \mathrm{DA}$ from striatal slices consisted of initial rapid and subsequent slow phases, as reported in the case of $\left[{ }^{3} \mathrm{H}\right] \mathrm{GABA}$ release in striatal slices (9). The rate constant (RC) and halftime $\left(t_{1 / 2}\right)$ were determined by compartmental analysis of the release curve of $\left[{ }^{3} \mathrm{H}\right] \mathrm{DA}$ 
from striatal slices. Buflomedil $\left(10^{-7}-10^{-5} \mathrm{M}\right)$ significantly shortened the $t_{1 / 2}$ and increased $R C$ in the slow phase dose-dependently. The high $\mathrm{K}^{+}(30 \mathrm{mM})$-evoked release of $\left[{ }^{3} \mathrm{H}\right] \mathrm{DA}$ was also significantly enhanced by the addition of buflomedil $\left(10^{-5} \mathrm{M}\right.$ ) (Fig. 1). On the other hand, buflomedil did cause any changes in the $\left[{ }^{3} \mathrm{H}\right] \mathrm{DA}$ release in the rapid phase.

Effect of buflomedil on striatal DA receptors: The $1 \mathrm{C} 50$ value of $\mathrm{SCH} 23390$, a $\mathrm{D}_{1}$ receptor antagonist, for $\left[{ }^{3} \mathrm{H}\right] \mathrm{SCH} 23390$ binding was $10^{-8} \mathrm{M}$. On the other hand, in vitro addition of buflomedil had no significant effect on the specific binding of $\left[{ }^{3} \mathrm{H}\right] \mathrm{SCH}$ 23390 to striatal DA $D_{1}$ type receptor. The IC50 value of $( \pm)$ sulpiride, a $D_{2}$ receptor antagonist, for the specific binding of $\left[{ }^{3} \mathrm{H}\right]$ spiperone was found to be $10^{-6} \mathrm{M}$. Under the same experimental conditions, it was found that the concentration of buflomedil that inhibited $\left[{ }^{3} \mathrm{H}\right]$ spiperone binding to 50 percent of the control level was $10^{-4} \mathrm{M}$. The specific binding of $\left[{ }^{3} \mathrm{H}\right]$ apomorphine to striatal $\mathrm{DA} \mathrm{D}_{3}$ type receptors, presynaptic autoreceptors of DA neurons $(18,19)$, was also inhibited to 50 percent of the control value by a high concentration $\left(10^{-4} \mathrm{M}\right)$ of buflomedil. However, the inhibitory potency of buflomedil on $\left[{ }^{3} \mathrm{H}\right]$ apomorphine binding was found to be significantly weaker than that of DA $\left(10^{-4} \mathrm{M}\right)$. the endogenous ligand of DA receptors (Fig. 2).

Effect of buflomedil on muscarinic cholinergic receptor in the striatum: There are several reports that presynaptic muscarinic
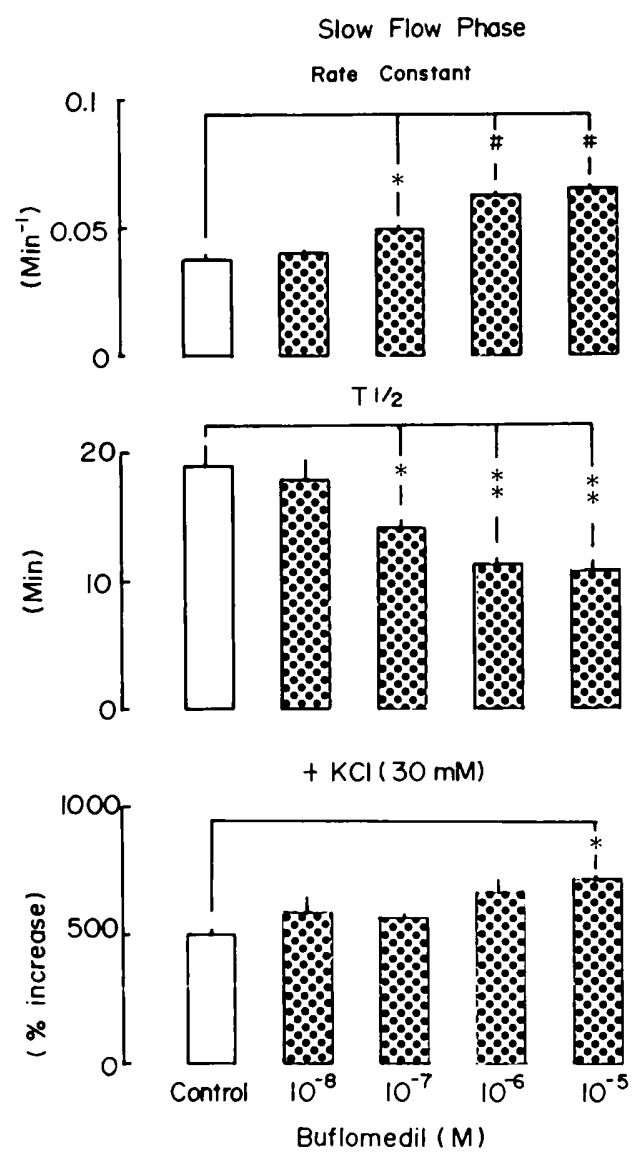

Fig. 1. Effect of buflomedil on $\left[{ }^{3} \mathrm{H}\right]$ DA release from striatal slices in vitro. The rate constant $\left(\mathrm{min}^{-1}\right)$ and $t_{1 / 2}$ (min) were calculated by compartmental analysis. Each bar represents the mean \pm S.E.M. obtained from four experiments. ${ }^{*} P<0.05,{ }^{*} P<0.01$ and $P<0.001$ represent a significant difference from each control value.

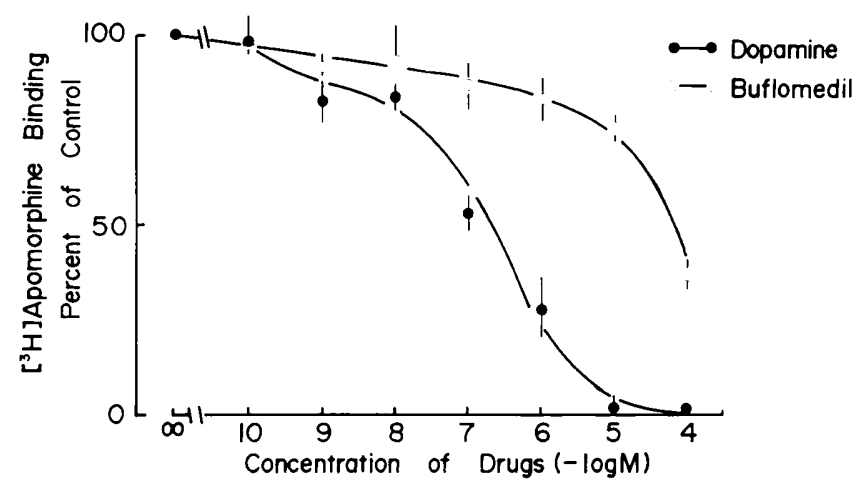

Fig. 2. Effects of buflomedil and dopamine on $\left[{ }^{3} \mathrm{H}\right]$ apomorphine binding to striatal synaptic membrane in vitro. Each point represents the mean \pm S.E.M. obtained from three experiments. Control value was $264.38 \pm 35.98 \mathrm{fmol} / \mathrm{mg}$ protein. 
cholinergic receptor may modulate the release of DA from striatal tissue (20-22). Therefore, the effect of buflomedil on muscarinic cholinergic receptor was investigated using $\left[{ }^{3} \mathrm{H}\right] \mathrm{ONB}$ as a ligand. Buflomedil and carbachol, a muscarine agonist, exhibited a similar inhibitory potency on the specific binding of $\left[{ }^{3} \mathrm{H}\right]$ QNB to striatal muscarinic cholinergic receptor (Fig. 3).

Effect of scopolamine on buflomedilinduced enhancement of striatal DA turnover: Single oral administration of buflomedil ( 300 $\mathrm{mg} / \mathrm{kg}$ ) to rats induced an increase in the contents of 3,4-dihydroxyphenylacetic acid (DOPAC) and homovanillic acid (HVA) without altering the content of DA as reported previously (7). Pretreatment with scopolamine $(0.5 \mathrm{mg} / \mathrm{kg})$, which did not alter the contents of DA and its metabolites, inhibited significantly the buflomedil-induced enhancement of striatal DA turnover (Fig. 4).

Effect of continuous administration of buflomedil on DA and muscarinic cholinergic receptors: Continuous oral administration of buflomedil ( $30 \mathrm{mg} / \mathrm{kg} \times 7$ days) had no significant effect on the specific bindings of $\left[{ }^{3} \mathrm{H}\right] \mathrm{SCH} 23390,\left[{ }^{3} \mathrm{H}\right]$ spiperone, $\left[{ }^{3} \mathrm{H}\right]$ apomorphine and $\left[{ }^{3} \mathrm{H}\right] \mathrm{QNB}$ in the striatum (Table 1).

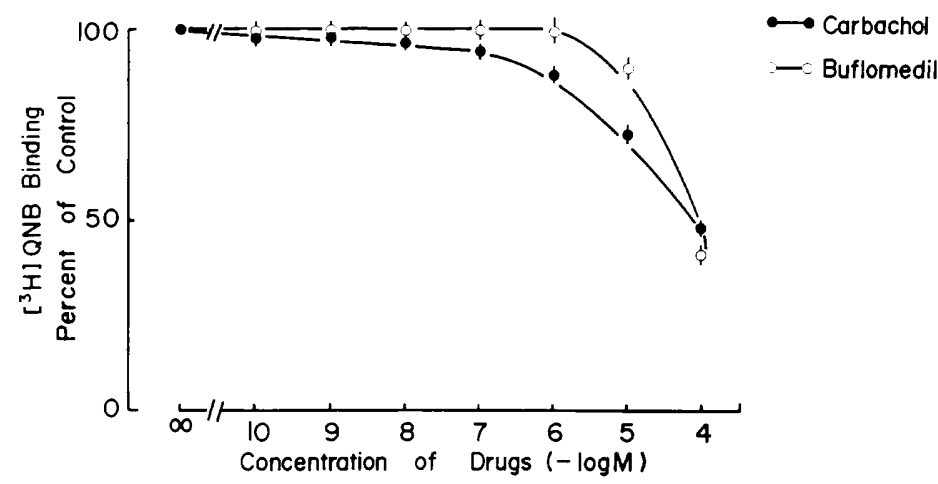

Fig. 3. Effects of buflomedil and carbacol on $\left[{ }^{3} \mathrm{H}\right]$ quinuclidinyl benzilate (QNB) binding to striatal particulate fraction in vitro. Each point represents the mean \pm S.E.M. obtained from three experiments. Control value was $693.18 \pm 19.69 \mathrm{fmol} / \mathrm{mg}$ protein.
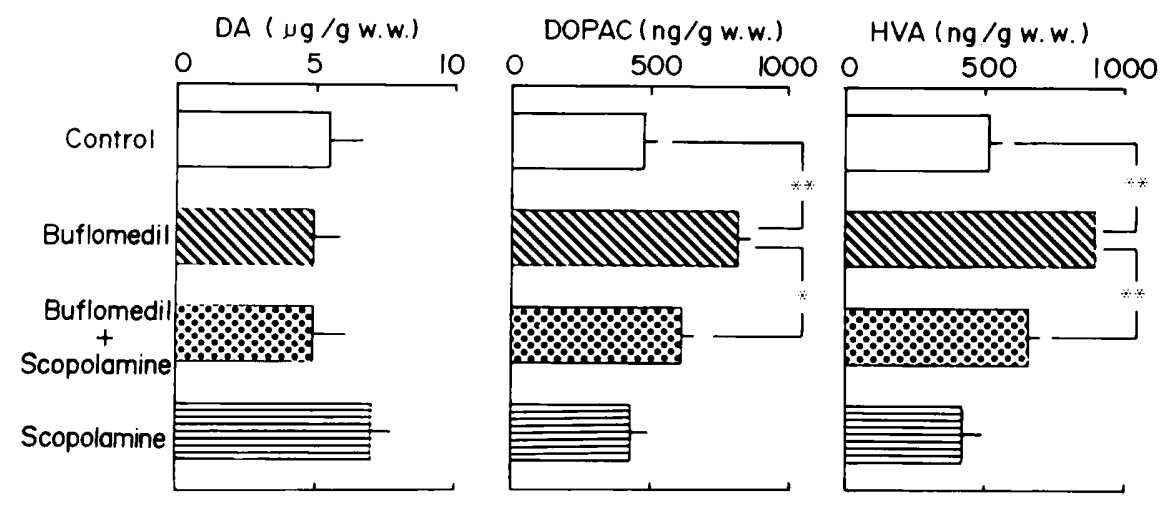

Fig. 4. Effect of scopolamine on buflomedil-induced enhancement of striatal DA turnover. Scopolamine $(0.5 \mathrm{mg} / \mathrm{kg})$ was administered subcutaneously to the rats at $30 \mathrm{~min}$ before the oral administration of bufiomedil $(300 \mathrm{mg} / \mathrm{kg}$ ). Each bar represents the mean \pm S.E.M. obtained from three experiments. ${ }^{*} \mathrm{P}<0.05$ and ${ }^{*} \mathrm{P}<0.01$ represent a significant difference from each control group or buflomedil-treated group. Abbreviations used: DA: dopamine, DOPAC: 3,4-dihydroxyphenylacetic acid, HVA: homovanillic acid. 
Table 1. Effect of continuous oral administration of buflomedil on three types of dopamine receptors and muscarinic cholinergic receptor in rat striatum

\begin{tabular}{lcc}
\hline Radioligand & \multicolumn{2}{c}{ Specific binding (fmol/mg protein) } \\
\hline & Control & Buflomedil \\
\hline$\left[{ }^{3} \mathrm{H}\right] \mathrm{SCH} 23390$ & $154.7 \pm 31.7$ & $234.7 \pm 31.9$ \\
$\left(\mathrm{D}_{1}\right.$ type $)$ & $83.6 \pm 10.4$ & \\
{$\left[{ }^{3} \mathrm{H}\right]$ spiperone } & $264.4 \pm 36.0$ & $98.4 \pm 11.5$ \\
$\left(\mathrm{D}_{2}\right.$ type $)$ & $1011.6 \pm 46.8$ & $230.8 \pm 20.2$ \\
{$\left[{ }^{3} \mathrm{H}\right]$ apomorphine } & \\
$\left(\mathrm{D}_{3}\right.$ type $)$ & & $1047.6 \pm 46.5$ \\
{$\left[{ }^{3} \mathrm{H}\right] \mathrm{ONB}$} & $($ Muscarinic $)$ & \\
\hline
\end{tabular}

Buflomedil $(30 \mathrm{mg} / \mathrm{kg}$ ) was given orally once daily for 7 days. Each value represents the mean \pm S.E.M. obtained from 4 to 8 experiments.

\section{Discussion}

We previously reported that buflomedil induced the enchancement of striatal DA turnover and that this effect of buflomedil was not due to the activation of DA biosynthesizing enzymes such as tyrosine hydroxylase and I-dopa decarboxylase (7). In the present study, the effect of buflomedil on the function of striatal DA neurons has been investigated to clarify the neurochemical mechanisms underlying buflomedil-induced enhancement of striatal DA turnover.

It is well-known that the reuptake of DA which is released into synaptic cleft plays a significant role in its inactivation. Buflomedil, however, was found to be ineffective on the reuptake process.

The release of preloaded [ $\left.{ }^{3} \mathrm{H}\right] \mathrm{DA}$ from striatal slices consisted of an initial rapid release phase followed by a slower rate of decline, as was reported for the release of $\left[{ }^{3} \mathrm{H}\right]$ GABA in the brain (9) and that of $\left[{ }^{3} \mathrm{H}\right]$ DA in the retina (23). It has been generally assumed that the rapid phase of spontaneous release represents the washout of preloaded substance from the extracellular space, while the slow phase represents its spontaneous release trom the intracellular pool, probably that in neurons (23). In this study, it has been found that in vitro addition of $10^{-7}-10^{-5} \mathrm{M}$ buflomedil induces the enhancement of the spontaneous release of $\left[{ }^{3} \mathrm{H}\right] \mathrm{DA}$ in the slow phase dose-dependently, while the enhancing effect of buflomedil on he high $\mathrm{K}^{+}$-evoked release of $\left[{ }^{3} \mathrm{H}\right] D A$ is exhibited at $10^{-5} \mathrm{M}$. These results suggest that the stimulatory effect of buflomedil on spontaneous DA release may be more potent than that on high $\mathrm{K}^{+}$-evoked DA release. Therefore, it is probable that buflomedil may accelerate striatal DA turnover through the augmentation of the spontaneous DA release rather than stimulation-evoked DA release.

It has been well documented that nerve terminals contain presynaptic receptors which are sensitive to the same released neurotransmitter (autoreceptor) and/or a different neurotransmitter substance (heteroreceptor). and these receptors play an important role in the regulation of release of various neurotransmitters at synapses (24). In fact, the DA autoreceptor is considered to modulate negatively DA release $(22,25,26)$. For instance, DA agonists such as apomorphine and amino-6,7-dihydroxy-1,2,3,4-tetrahydronaphthalene (ADTN) reduced the stimulation-evoked release of [ $\left.{ }^{3} \mathrm{H}\right] \mathrm{DA}$ from striatal slices (22-24), while DA antagonists such as $(-)$ sulpiride and haloperidol enhanced the evoked release of DA (24). Furthermore, it has been suggested that the $\mathrm{DA} \mathrm{D}_{3}$ type receptor may represent a presynaptic DA autoreceptor $(18,19)$. On the other hand. previous studies on the negative control of DA release via presynaptic autoreceptors have led to the conclusion that these receptors exhibit pharmacological properties of DA $D_{2}$ type receptors $(25,27,28)$. Buflomedil, however, showed a low affinity for both $D_{2}$ 
and $D_{3}$ type receptors as compared with those of typical antagonists and DA, respectively. These results suggest that buflomedil may enhance DA release via a process other than the inhibition of presynaptic DA autoreceptors.

It has been also suggested that stimulation of presynaptic muscarinic receptors as heteroreceptors may facilitate striatal DA release (20-22). For example, muscarine agonists such as acetylcholine, carbachol and oxotremorine were found to potentiate $\left[{ }^{3} \mathrm{H}\right]$ DA release from striatal slices, and these potentiations were antagonized by atropine, a muscarinic antagonist $(20,21)$. In this study, carbachol, a muscarinic agonist. showed an inhibitory effect on $\left[{ }^{3} \mathrm{H}\right] \mathrm{QNB}$ binding from $10^{-6} \mathrm{M}$ to $10^{-4} \mathrm{M}$, dosedependently, as described previously (29). On the other hand, buflomedil and carbachol showed similar inhibitory potencies on $\left[{ }^{3} \mathrm{H}\right]$ QNB binding to the striatal muscarinic cholinergic receptors in the concentrations employed in this study. Furthermore, scopolamine, a muscarinic antagonist, inhibited the buflomedil-induced enhancement of striatal DA turnover that probably resulted from the increase of DA release. These results suggest that the enhancing effect of buflomedil on DA release may be, at least in part, due to the activation of striatal muscarinic heteroreceptor.

Recently, muscarinic receptor subtypes, $M_{1}$ and $M_{2}$ receptors, have been proposed to exist on the basis of their different affinities to pirenzepine in the central nervous system (30). Furthermore, Raiteri et al. (21) has suggested that muscarinic $M_{1}$ type receptor which shows a high affinity for pirenzepine may modulate striatal DA release as a heteroreceptor. Therefore, it should be clarified in future studies whether or not buflomedil has a high affinity to $M_{1}$ type receptors. Similarly, it has been reported that glutamate receptors and GABA receptors may regulate DA release from striatal tissues $(31-33)$. Therefore, possible involvement of alterations in these receptors following buflomedil administration may also be considered in future studies.

DA agonist has been reported to alter DA receptors following continuous adminis- tration. For instance, continuous administration of D-methamphetamine, a DA releaser (34) or pergolide, a direct DA receptor agonist (35), reduces the binding of $\left[{ }^{3} \mathrm{H}\right]$ spiperone in rat striatum $(34,35)$. On the other hand, it has also been reported that chronic administration of oxotremorine, a muscarinic agonist, reduces the binding of $\left[{ }^{3} \mathrm{H}\right]$ QNB in rat brain (36). Therefore, it is anticipated that continuous administration of buflomedil may also alter DA and/or muscarinic cholinergic receptors through long-term stimulations of DA release and/or muscarinic cholinergic receptor. However, continuous in vivo administration of buflomedil (30 mg/ $\mathrm{kg} \times 7$ days), which was reported to facilitate striatal DA turnover (7). had no effect on the bindings of $\left[{ }^{3} \mathrm{H}\right]$ $\mathrm{SCH} 23390,\left[{ }^{3} \mathrm{H}\right]$ spiperone, $\left[{ }^{3} \mathrm{H}\right]$ apomorphine and $\left[{ }^{3} \mathrm{H}\right] \mathrm{QNB}$ to striatal $\mathrm{D}_{1}, \mathrm{D}_{2}, \mathrm{D}_{3}$ and muscarinic cholinergic receptors, respectively. Although it is not clear why in vivo administration of buflomedil did not induce significant changes in striatal DA and/or muscarinic receptors, a larger dose of buflomedil or longer period of administration may be required to induce functional alterations in these receptors in vivo.

In conclusion, buflomedil may accelerate striatal DA turnover through the augmentation of DA release, and the activation of muscarinic cholinergic receptor may be involved in this enhancement of striatal DA release induced by buflomedil.

\section{References}

1 Duteil, J., Henry, M., Bouett, G., Pessonier, A., Assous, E. and Beurier, J.: Effet du (trimethoxy2.4,6) phenyl-(pyrrolidine-3)propylcetone ou LL 1656, sur le débit femoral du chein. Comparison avec le papaverine. Therapie 30, 207219 (1975)

2 Toda, N., Okunishi, H., Okamura, T. and Miyazaki, M.: Effect of buflomedil on isolated dog arteries. Arch. Int. Pharmacodyn. Ther. 266, 117-130 (1983)

3 Ehringer, H., Konecny, U., Ingerle, H., Minar, E. and Wiethoff, E.: Effect of buflomedil on perfusion of the extremities in peripheral vascular disease. In Microcirculation and Ischemic Diseases: Advances in Diagnosis and Therapy, Edited by Messner, K. and Fagrel!, B., p. 305312. Academy Proffessional Information 
Services, Inc., New York (1981)

4 Courbier, R., Bergeron, P. and Fouque, R.: Double-blind capillaroscopic study of the activity of buflomedil in Raynaud's syndrome: a report on 80 cases. Angiology 32, 676-678 (1981)

5 De Nicola, P. and Tassi, G.: Cerebrovascular insufficiency in old age: long term treatment with buflomedil. In Microcirculation and Ischemic Diseases: Advance in Diagnosis and Therapy, Edited by Messner, K. and Fagrell, B., p. 337345. Academy Proffessional Information Services, Inc., New York (1981)

6 Vázquez de Negrotto, O., Aquerre de Curbelo, E., Santini de Souto, H., Negrotto, A., Medici, M., Suarez, H. and Fusler, B.: Action of buflomedil in vertebrobasilar circulatory insufficiency. In Microcirculation and Ischemic Vascular Diseases: Clinical and Therapeutic Approaches, Edited by Couto, B., p. 169-191. Biomedical Information Cooperation, New York (1982)

7 Koda, H., Hashimoto, T. and Kuriyama, K.: Effect of buflomedil (4-(1-pyrrolidinyl)-1-(2,4,6 -trimethoxy phenyl)-1-butanone hydrochloride) on neurotransmitters in the striatum and substantia nigra. Japan. J. Pharmacol. 47, 253-259 (1988)

8 Glowinski, J. and Iversen, L.L.: Regional studies of catacholamines in the rat brain-l. The disposition of $\left[{ }^{3} \mathrm{H}\right]$ norepinephrine, $\left[{ }^{3} \mathrm{H}\right]$ dopamine and $\left[{ }^{3} \mathrm{H}\right] D O P A$ in various regions of the brain. J. Neurochem. 13, 655-669 (1966)

9 Kuriyama, K., Kanmori, K., Taguchi, J. and Yoneda, $Y .:$ Stress-induced enhancement of supression of $\left[{ }^{3} \mathrm{H}\right] \mathrm{GABA}$ release from striatal slices by presynaptic autoreceptor. J. Neurochem. 42, 943-950 (1984)

10 Solomon, A.K.: Compartmental analysis. In Mineral Metabolism, Edited by Comer, C.L. and Bronner, F., Vol. 1A, p. 119-166. Academic Press, New York (1960)

11 Lønsmann Poulsen, H., Jensen, H.E. and Parving, H.H.: Extracellular fluid volume determind by a single injection of inulin in men with untreated essential hypertension. J. Clin. Lab. Invest. 37, 691-696 (1977)

12 Arana, G.W., Lamont, J.S., Baldessarini, R.J., Teicher, M.H., Neumeyer, J.L. and Cohen, B.M.: Binding of $\left[{ }^{3} \mathrm{H}\right]$ apomorphine to an aporphine binding site as well as to dopamine sites in tissue from bovine caudate nucleus. Neuropharmacology 23, 885-892 (1984)

13 Niznik, H.B., Otsuka, N.Y., Dumbrille-Ross, A., Grigoriadis, D., Tirpak, A. and Seeman, P.: Dopamine $D_{1}$ receptors characterized with $\left[{ }^{3} \mathrm{H}\right]$ -
SCH23390. J. Biol. Chem. 261, 8397-8406 (1986)

14 Grigoriadis, D. and Seeman, P.: Complete conversion of brain $D_{2}$ dopamine receptors from high- to the low-affinity state for dopamine agonist, using sodium ions and guanine nucleotide. J. Neurochem. 44, 1925-1935 (1985)

15 Yamamura, H.I. and Snyder, S.H.: Muscarinic cholinergic binding in rat brain. Proc. Natl. Acad. Sci. U.S.A. 71, 1725-1729 (1974)

16 Lowry, O.H., Rosebrough, N.J., Farr, A.L. and Randall, R.J.: Protein measurement with the Folin phenol reagent. J. Biol. Chem. 193, 265275 (1951)

17 Wagner, J., Vitali, P., Palfreyman, M.G., Zraika, M. and Huot, S.: Simultaneous determination of 3.4-dihydroxyphenylalanine, 5-hydroxytryptophan, dopamine, 4-hydroxy-3-methoxyphenylalanine, norepinephrine, 3.4-dihydroxyphenylacetic acid, homovanillic acid, serotonin and 5hydroxyindoleacetic acid in rat cerebrospinal fluid and brain by high-performance liquid chromatography with electrochemical detection. J. Neurochem. 38, 1241-1254 (1982)

18 Titeler, M., Tedesco, J.L. and Seeman, P.: Selective labeling of presynaptic and receptors by ${ }^{3} \mathrm{H}$-dopamine, ${ }^{3} \mathrm{H}$-apomorphine and ${ }^{3} \mathrm{H}$ clonidine: labeling of postsynaptic sites by ${ }^{3} \mathrm{H}$ neuroleptics. Life Sci. 23, 587-592 (1978)

19 Tieteler, M., List, S. and Seeman, P.: Highaffinity dopamine receptors $\left(D_{3}\right)$ in rat brain. Commun. Psychopharmacol. 3, 411-420 (1979)

20 Lehmann, J. and Langer, S.Z.: Muscarinic receptors in dopamine terminals in the cat caudate nucleus: neuromodulation of $\left[{ }^{3} \mathrm{H}\right]-$ dopamine release in vitro by endogenous acetylcholine. Brain Res. 248, 61-69 (1982)

21 Raiteri, M., Leardi, R. and Marchi, M.: Heterogeneity of presynaptic muscarinic receptors regulating neurotransmitter release in the rat brain. J. Pharmacol. Exp. Ther. 228, 209-214 (1984)

22 Diliberto, P.A., Garrett, L.J., James, M.K. and Cubeddu, L.X.: Ionic mechanism of dopaminergic and muscarinic auto- and heteroreceptor activation in superfuged striatal slices: Role of extracellular chloride. J. Pharmacol. Exp. Ther. 240. 795-801 (1987)

23 Nishimura, C. and Kuriyama, K.: Alterations in the retinal dopaminergic neuronal system in rats with streptozotocin-induced diabetes. J. Neurochem. 45, 448-455 (1985)

24 Langer, S.Z.: Presynaptic regulation of the release of catecholamines. Pharmacol. Rev. 32, 337-369 (1980)

25 Starke, K., Spath, L., Long, J.D. and Adelung, C.: 
Further functional in vitro comparison of preand postsynaptic dopamine receptors in the rabbit caudate nucleus. Naunyn Schmiedebergs Arch. Pharmacol. 323, 298-306 (1983)

26 Kamal, L.A., Arbilla, S. and Langer, S.Z.: Presynaptic modulation of the release of dopamine from the rabbit caudate nucleus: differences between electrical stimulation, amphetamine and tyramine. J. Pharmacol. Exp. Ther. 216, 592-598 (1981)

27 Stoof, J.C., De Boer, T., Sminia, P. and Mulder, A.H.: Stimulation of $D_{2}$-dopamine receptors in rat neostriatum inhibits the release of acetylcholine and dopamine but does not affect the release of $\gamma$-aminobutyric acid, glutamate or serotonin. Eur. J. Pharmacol. 84, 211-214 (1982)

28 Lehmann, J., Briley, M. and Langer, S.Z.: Characterization of dopamine autoreceptor and $\left[{ }^{3} \mathrm{H}\right]$ spiperone binding sites in vitro with classical and novel dopamine receptor agonists. Eur. J. Pharmacol. 88, 11-26 (1983)

29 Aronstam, R.S. and Eldefrawi, M.E.: Reversible conversion between affinity states for agonists of the muscarinic acetylcholine receptor from rat brain. Biochem. Pharmacol. 28, 701-703 (1979)

30 Watson, M., Yamamura, A.I. and Roeske, W.R.: A unique regulatory profile and regional distribution of ${ }^{3} \mathrm{H}$-pirenzepine binding in the rat provide evidence for distinct $M_{1}$ and $M_{2}$ muscarinic receptor subtypes. Life Sci. 31, 20192023 (1983)

31 Roberts, P.J. and Anderson, S.D.: Stimulatory effects of L-glutamate and related amino acids on ${ }^{3} \mathrm{H}$-dopamine release from striatum: an in vitro model for glutamate actions. J. Neurochem. 32, 1539-1545 (1979)

32 Giorguieff, M.F., Kemel, M.L. and Glowinski, J.: Presynaptic effect of L-glutamic acid on dopamine release in rat striatal slices. Neurosci. Lett. 6, 77-78 (1977)

33 Giorguieff, M.F., Kemel, M.L., Glowinski, J. and Besson, M.J.: Stimulation of dopamine release by GABA in rat striatal slices. Brain Res. 139 , 115-130 (1978)

34 Kashihara, K., Sato, M., Fujiwara, Y., Yasuda, J., Fukuda, K., Harada. T. and Otsuki, S.: Chronological change in abnormal behaviors produced by long-term methamphetamine administration in rat. Japan. J. Psychopharmacol. 5, 261-270 (1985) (in Japanese)

35 Jenner, P. and Marsden, C.D.: Chronic pharmacological manipulation of dopamine receptors in brain. Neuropharmacology 26, 931-940 (1987)

36 Marks, M.T., Artman, L.D., Patinkin, D.M. and Collins, A.C.: Cholinergic adaptations to chronic oxotremorine infusion. J. Pharmacol. Exp. Ther. 218, 337-343 (1981) 